\title{
The Successful Treatment of Congenital Esophageal Stenosis by Endoscopic Dilatation
}

\section{Endoskopik Dilatasyon ile Bașarıyla Tedavi Edilen Doğumsal Özofagus Darlığı}

\author{
Tuğba Koca, Selim Dereci, Mustafa Akçam \\ Süleyman Demirel University Faculty of Medicine, Department of Pediatric Gastroenterology, Hepatology and Nutrition, Isparta, Turkey
}

\begin{abstract}
Congenital esophageal stenosis is a rarely seen entity and depending on the degree of severity, symptoms may start in the newborn period or in later months. Symptoms in the early period enable early diagnosis. However, as symptoms are similar to those of gastro-esophageal reflux a long period of time may be spent on the incorrect diagnosis of gastro-esophageal reflux followed by unnecessary treatment. There is no consensus on treatment approach. The case presented is of a 10-month-old male patient who was transferred to our clinic when the desired response was not obtained from the treatment of gastro-esophageal reflux which had been diagnosed. The patient was subsequently diagnosed with esophagus stenosis and successfully treated with the balloon and bougie dilatation method. Keywords: Dilation, gastroesophageal reflux, congenital esophageal stenosis, treatment
\end{abstract}

ÖZ

Doğumsal özofagus darlığı nadir görülen bir antite olup, ağılık derecesine göre yakınmalar yenidoğan döneminde veya daha sonraki aylarda başlayabilir. Erken dönemde yakınmaların başlaması tanının erken konmasına neden olabilir. Bununla birlikte yakınmaların gastroözofagial reflü yakınmalarına benzerlik göstermesi nedeni ile uzun süre gastroözofagial reflü tanısı ile takip edilip gereksiz tedavilerle vakit geçirilebilir. Tedavi yaklaşımı konusunda fikir birliği yoktur. Burada gastroözofagial reflü tanısı ile izlenen ve tedaviye istenen yanıt alınamayınca kliniğimize sevk edilen, özofagus darlığı tanısı konularak balon ve buji dilatasyon yöntemi ile başarılı bir şekilde tedavi edilen 10 aylik erkek olgu sunulmuştur.

Anahtar Kelimeler: Dilatasyon, gastroözofagial reflü, doğumsal özofagus darlığı, tedavi

\section{Introduction}

Congenital esophageal stenosis (COS) is an extremely rare malformation, and diagnostic criteria and standard treatment have not been completely established. The actual incidence is unknown and it is estimated to be 1 per 25,00050,000 births (1). In the neonatal period, COS cases are asymptomatic. The majority are diagnosed at 4-10 months when they begin solid food nutrition and there are evident clinical signs of food regurgitation (2). Patients may be followed up for a long time with an incorrect diagnosis of reflux. The treatment choices are dilatation methods such as with balloon or bougie or surgery $(3,4)$.

Lacerations and perforations of the esophagus are complications of conservative treatment (3). The surgical method is a severe method with complications for pediatric patients. Therefore, the surgical method should only be selected for those who do not respond to conservative methods (5). The case presented and discussed is of a 10-month-old male patient who was brought to our clinic when the desired response was not obtained from treatment for the diagnosis of reflux. The patient was subsequently 
diagnosed with esophagus stenosis and successfully treated with bougie or balloon dilatations.

\section{Case Report}

A 10-month-old male infant presented with complaints of vomiting which had been ongoing since the age of one month. When weaning was started and semisolid meals were introduced, the vomiting increased. Parents reported no complaint with ingestion of liquid food. The parents had taken the infant to several healthcare institutions and despite anti-reflux treatment, the vomiting continued, no benefit was seen from the anti-reflux treatment and the complaints continued with increasing intensity. In the physical examination, height and weight were in the 10-25 percentile, system examinations were natural and routine laboratory test results were normal. During an esophageal-stomach barium radiograph, narrowness was observed in the mid-distal segment of the esophagus and widening in the proximal section but barium reflux was not detected (Figure 1). In the upper gastrointestinal system endoscopy, it was seen that from the incisor teeth onwards for $18 \mathrm{~cm}$ there was a firm stenosis that did not allow the passage of the endoscope without mucosal alterations and, no macroscopic alterations owing to reflux esophagitis. This investigation led us to exclude the diagnosis of reflux esophagitis and it documented the presence of a COS (Figure 2). There were food remnants in the esophagus lumen. Thorax computed tomography showed a regular thickening of the esophageal wall in the absence of cartilagenous remnants. With the diagnosis of congenital esophageal stenosis, balloon dilatation was made under fluoroscopy with general anesthesia. On the $15^{\text {th }}$ day after the first application, when the opening was seen to be insufficient with balloon dilatation, Savary-Gillard bougie dilatation was applied in the same session. After this session the complaint of vomiting was resolved and the patient was able to tolerate semi-solid food. Follow-up examinations of the region of narrowness were made by endoscopy at 1-month intervals and dilatation was applied 5 more times. A total of 7 sessions of balloon and Savary-Gillard bougie dilatation combinations were applied without complications (Figure 3). In the $6^{\text {th }}$ month, the esophageal narrowing was determined to have completely recovered on the repeated esophageal-stomach barium radiograph (Figure 4). As the patient was able to be easily fed with solid food, he was observed to rapidly gain weight. At one year after the end of the treatment, the development of the patient was seen to be normal and there were no complaints.

Written informed consent was obtained from the patient's parents.

\section{Discussion}

There are 3 histological types of COS:

1. Segmentary hypertrophy of the muscularis mucosa or submucosal layers,
2. The presence of a membranous curtain or diaphragm,

3. Narrowness as a result of accumulated cartilage structure tracheobronchial tissue remains in the esophagus wall $(5,6)$.

COS is often related to esophagus atresia. COS that is not accompanied by esophagus atresia is rarely diagnosed in the neonatal period. Complaints start with the intake of semisolid food, as seen in the current case, and diagnosis may be delayed until the second decade of life (3). Patients may present with complaints of insufficient weight gain, aspiration pneumonia and dysphagia. A barium esophagogram is used in diagnosis. There is a limited amount of data from a small series related to the treatment approach and results.

Surgery, such as resection was formerly suggested as the first therapeutic strategy for pediatric cases with stenosis (5). In these cases, hospital stay would be prolonged and thoracotomy surgery might be necessary.

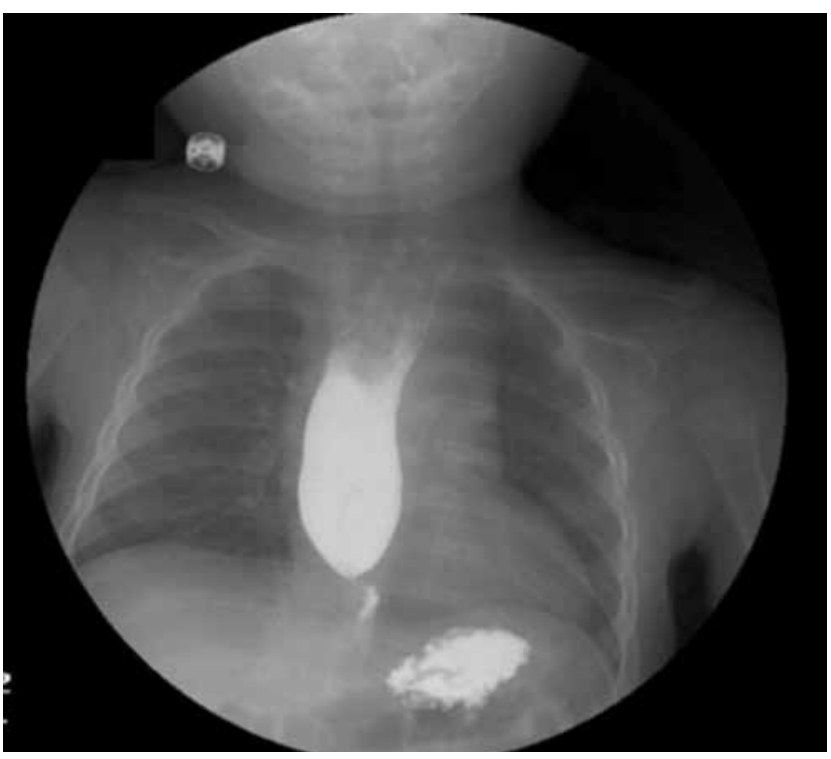

Figure 1. Narrowness in the distal esophagus and widening in the proximal seen on barium radiograph

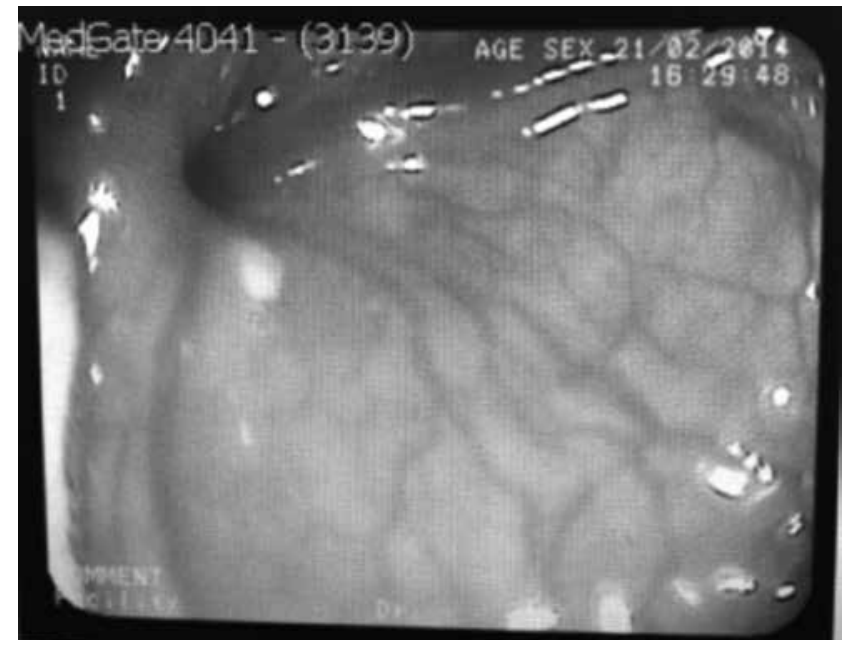

Figure 2. Endoscopic appearance of esophageal stenosis 


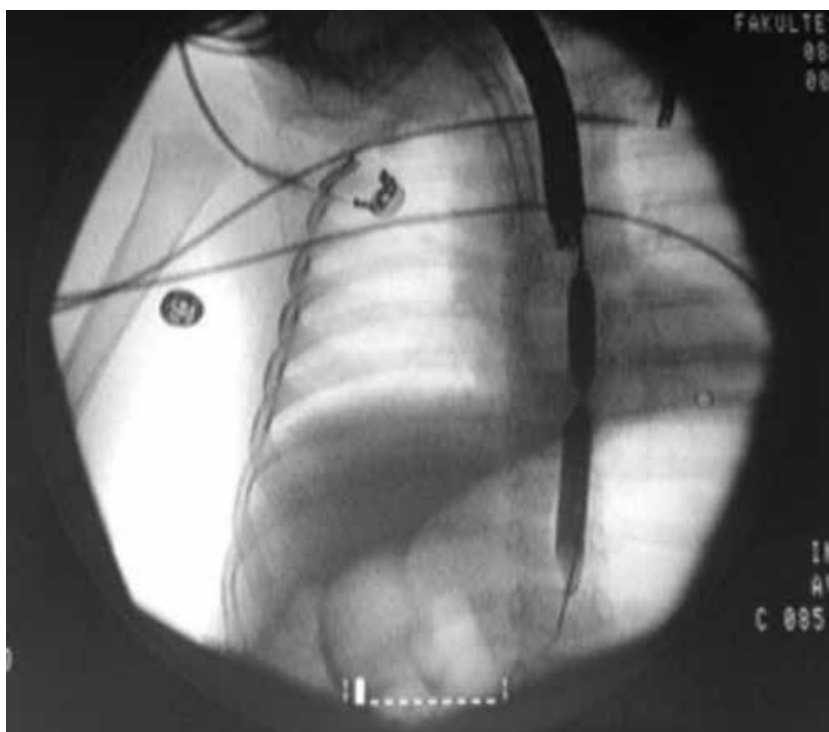

Figure 3. Balloon dilation of esophageal stenosis

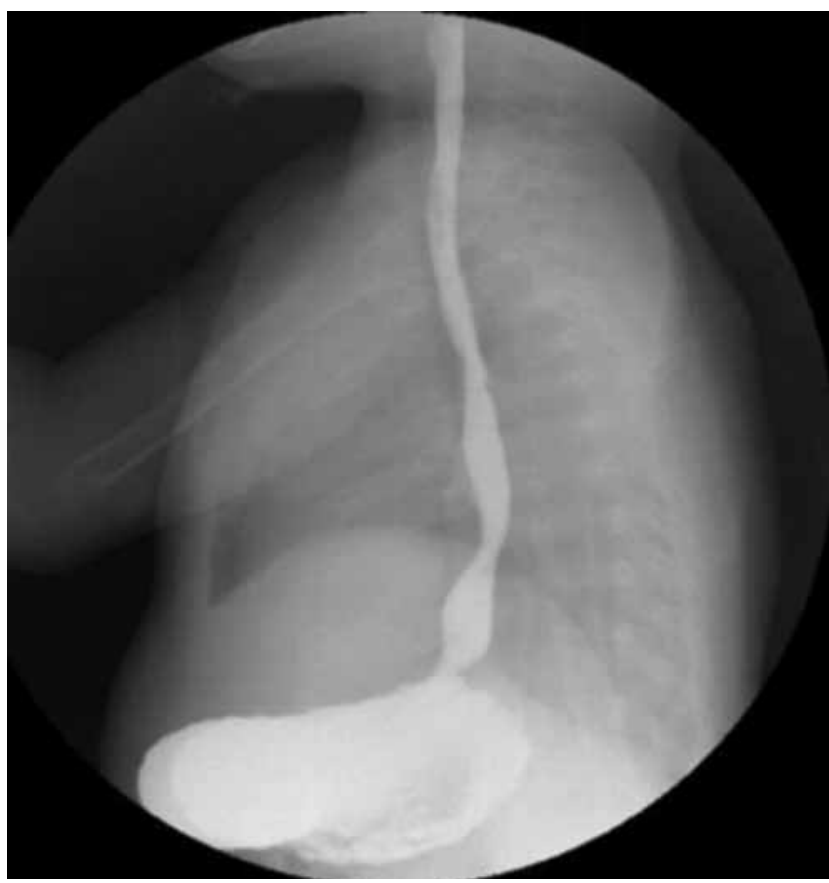

Figure 4. Barium esophagus-stomach radiograph six months after the endoscopic dilatations

Despite the risk of this complication, when consideration is given to the complications which may develop in patients undergoing surgical resection (operation risk, short esophagus, gastroesophageal reflux stricture, the need for postoperative anti-reflux operation), conservative dilatation methods should be considered (7). While some studies have reported successful conservative treatment, there are a limited number of cases with high rates of complications. A greater number of reports have stated that relatively good results have been obtained and emphasized that it is certainly a safer option (1-7). In the reported studies, dilatation was applied a mean 2.5 times (range, 1-10) in each patient and of the techniques used, no superiority or disadvantage was demonstrated. In the current case, 7 sessions of balloon and Savary-Gillard bougienage were applied without any complications and recovery was achieved without any need for surgery. Therefore, dilation for all types of COS has been accepted by some groups as an appropriate first-line treatment because it is effective, minimally invasive and safe $(1,6)$. The common complications of conservative procedures include esophageal perforation, recurrent stenosis, bleeding, sepsis, and mediastinitis (7).

\section{Conclusion}

COS is a rare condition with respect to gastro-esophageal reflux and should be suspected when a mother reports her infant has vomiting and difficulty swallowing solid foods. Endoscopic dilatation can be a useful, nonsurgical approach in the treatment of COS. The optimal frequency and time of such procedures is not well established and is largely individualized. Surgery should be recommended for patients who have not responded to dilatation.

\section{Ethics}

Informed Consent: Written informed consent was obtained from the patient's parents.

Peer-review: Externally peer-reviewed.

\section{Authorship Contributions}

Surgical and Medical Practices: Mustafa Akçam, Tuğba Koca, Selim Dereci, Concept: Mustafa Akçam, Design: Mustafa Akçam, Data Collection or Processing: Selim Dereci, Analysis or Interpretation: Tuğba Koca, Literature Search: Tuğba Koca, Writing: Tuğba Koca.

Conflict of Interest: No conflict of interest was declared by the authors.

Financial Disclosure: The authors declared that this study has received no financial support.

\section{References}

1. Amae $S$, Nio M, Kamiyama $T$, et al. Clinical characteristics and management of congenital esophageal stenosis: a report on 14 cases. J Pediatr Surg 2003;38:565-70.

2. Murphy SG, Yazbeck S, Russo P. Isolated congenital esophageal stenosis. J Pediatr Surg 1995;30:1238-41.

3. Michaud L, Coutenier F, Podevin G, et al. Characteristics and management of congenital esophageal stenosis: findings from a multicenter study. Orph J Rare Diseases 2013;8:186.

4. Elhalaby EA, Elbarbary MM, Hashis AA, Kaddah SN, Hamza AF. Congenital esophageal stenosis: To dilate or to resect. Ann Pediatr Surg 2006;2:2-9.

5. Romeo E, Foschia F, de Angelis P, et al. Endoscopic management of congenital esophageal stenosis. J Pediatr Surg 2011;46:838-41.

6. Jones DW, Kunisaki SM, Teitelbaum DH, Spigland NA, Coran AG. Congenital esophageal stenosis: the differential diagnosis and management. Pediatr Surg Int 2010;26:547-51.

7. Vasudevan SA, Kerendi F, Lee H, Ricketts RR. Management of congenital esophageal stenosis. J Pediatr Surg 2002;37:1024-6. 